\title{
Brown bear (Ursus arctos) body size, condition, and productivity in the Arctic, 1977-2016
}

\author{
Grant V. Hilderbrand ${ }^{1}\left[\right.$ C Kyle Joly ${ }^{2} \cdot$ Mathew S. Sorum $^{2} \cdot$ Matthew D. Cameron $^{2} \cdot$ David D. Gustine $^{3}$
}

Received: 25 September 2018 / Revised: 26 March 2019 / Accepted: 29 March 2019 / Published online: 5 April 2019

(c) The Author(s) 2019

\begin{abstract}
The Arctic is generally warming with lengthening growing seasons that can influence individuals, populations, and communities. However, temperature data indicate that the changes are largely local and variable. We compared body size, body condition, and productivity among four Arctic brown bear (Ursus arctos) studies separated in time and space from 1977 to 2016. As body size, condition, and productivity varied among populations, local conditions, both biotic and abiotic, appear to influence the size, condition, and productivity of individual bears and, thus, bear populations. We conclude that current local studies are critical in informing management decisions, because extrapolations from concurrent adjacent studies or reliance on past local studies may not represent the present condition of an Arctic brown bear population.
\end{abstract}

Keywords Arctic $\cdot$ Body condition $\cdot$ Body size $\cdot$ Brown bear $\cdot$ Litter size $\cdot$ Productivity $\cdot$ Ursus arctos

\section{Introduction}

Brown bears (Ursus arctos) occupy a wide variety of ecosystems and climates that reflect their plasticity in diet, physiology, and body size as they adapt to local conditions (Mowat and Heard 2006; Hilderbrand et al. 2018a, b). One life history trait consistent among female brown bears is the birth of offspring during winter dormancy with its multi-annual costs of cub production, lactation, and rearing that rely largely on body nutrient stores during winter hypophagia (Farley and Robbins 1995; Hilderbrand et al. 2000). Greater quality, quantity, and availability of food resources directly and positively influence female brown bear body size, condition, and productivity. Salmon (Oncorhynchus spp.) are among the most influential resources due to their nutritional content and availability prior to denning during the hyperphagic fall period prior (Hilderbrand et al. 1999). However, when salmon are available, the degree of salmon consumption can

Grant V. Hilderbrand

ghilderbrand@usgs.gov

1 Alaska Science Center, U.S. Geological Survey, 4210 University Drive, Anchorage, AK 99508, USA

2 National Park Service, Gates of the Arctic National Park and Preserve, 4175 Geist Road, Fairbanks, AK 99709, USA

3 National Park Service, Grand Teton National Park, PO Box 170, Moose, WY, USA vary substantially from one bear to another (Deacy et al. 2016; Mangipane et al. 2017).

Global warming is occurring in the Arctic at more than twice the global rate and is affecting terrestrial systems through physical processes such as increased permafrost thaw and altering hydrology and nutrient dynamics (IPCC 2007; Comiso and Hall 2014; Gonzales et al. 2018). Spring snow has been melting earlier and, correspondingly, greenup dates have occurred about 6 days earlier from 2000 to 2016 in the Arctic (Swanson 2017). In some cases, composition of vegetation communities is also changing (Hinzman et al. 2013). Plant productivity is increasing in Arctic tundra (Tape et al. 2006; Verbyla 2008), although apparent effects of warming vary spatially and temporally. Not all regions have undergone or will undergo changes of the same magnitude or rate (Clement et al. 2013; Van Hemert et al. 2015; Fig. 1).

The potential effects of climate change on Arctic omnivores, such as brown bears, have received less conceptual consideration than ice-dependent marine mammals or terrestrial herbivores (Van Hemert et al. 2015). The inherent dietary and physiological plasticity seen in brown bears, both across and within populations, add additional complexity and uncertainty when predicting the effects of natural resource management decisions related to appropriate harvest levels, human access, and development (Hilderbrand et al 2018a; Wilson et al. unpublished work). Lengthening 
Fig. 1 Consecutive days above freezing (1a) and mean July temperatures (1b), 1975-2017, in Deadhorse, Kotzebue, and Bettles, Alaska, which are near the study areas (Fig. 2). All data are from the National Ocean and Atmospheric Administration's National Centers for Environmental Information (https:// www.ncdc.noaa.gov)
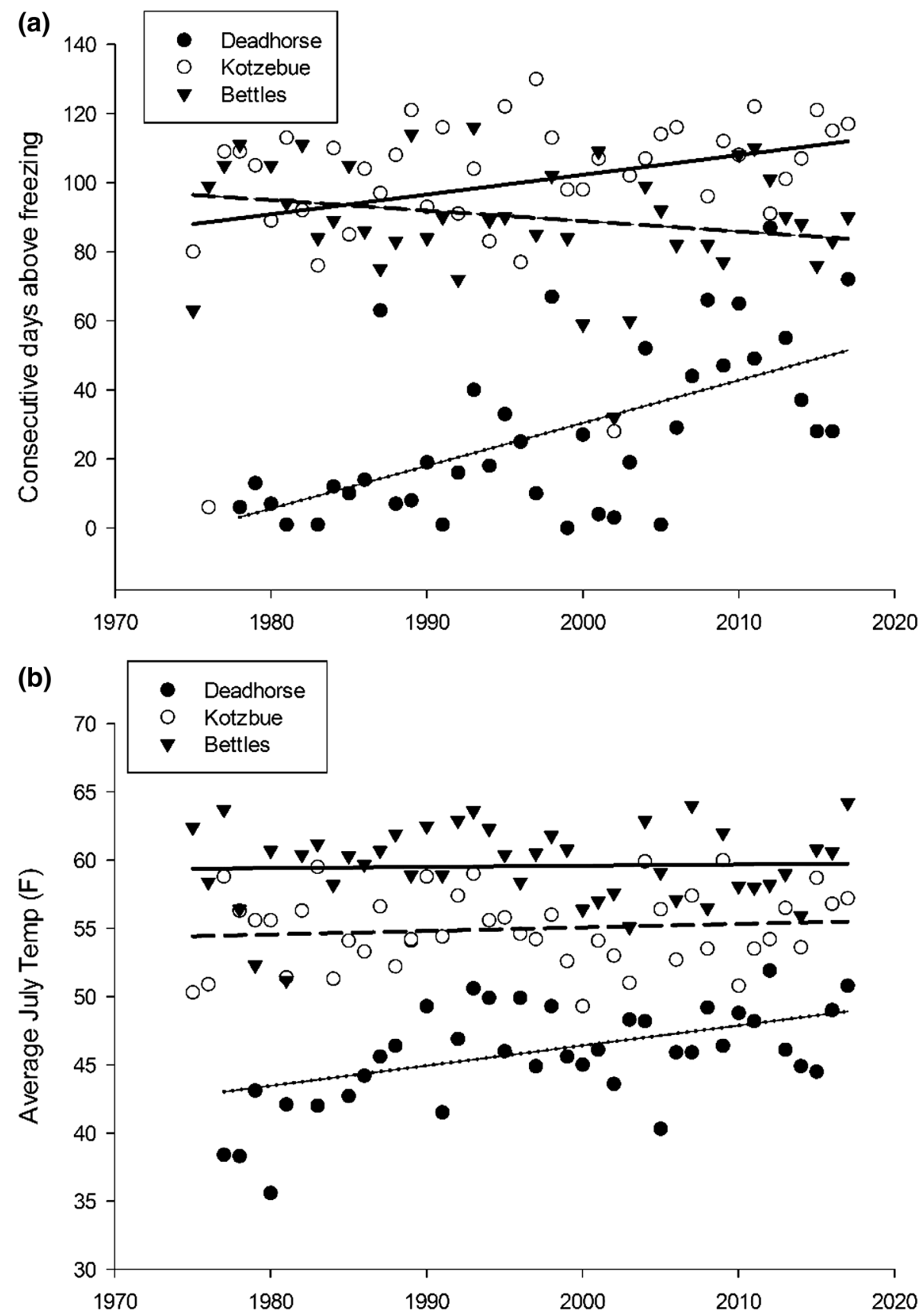

growing seasons may be advantageous to Arctic brown bears by allowing for more food resources and a shortened period of dormancy (e.g., denning season) which would reduce the demand for body stores to survive and reproduce in winter. However, depending on the quality of the "additional" food available, an extended non-dormant period may, on balance, negatively influence condition and productivity.

Physiography strongly influences climate, vegetation, and wildlife. In the Arctic, higher elevations and lower soil $\mathrm{pH}$ are associated with less productive plant communities (Raynolds et al. 2006). Edaphic conditions also strongly influence community species diversity (Holt et al. 2007).
Less productive habitat could directly affect brown bear physiology and demographics. Also, as brown bears select for steeper slopes and well-drained soils, physiography strongly influences brown bear denning selection (Pigeon et al. 2014, 2016).

Ultimately, a mechanistic understanding of the complex processes that affect brown bear body size, condition, and productivity benefits wildlife scientists, managers, and policy makers. In this study, our objective was to compare metrics of individual health related to body size (body length, skull size), body condition (body mass, body mass index, Fulton's index), and productivity (spring litter size) among 
four prior studies of Arctic brown bear populations that span almost 40 years (1977-2016). We predicted that these measures may differ among study sites due to local factors including but not limited to temperature, physiography, growing season, and food quality and abundance.

\section{Methods}

We compiled and analyzed data from four prior studies of Alaskan Arctic brown bear populations: (1) Western Brooks Range (WBR), 1977-1979 (Reynolds and Hechtel 1989) (2) Arctic National Wildlife Refuge (ANWR), 1982-1984 (Garner et al. 1984) (3) Noatak 1986-1989 (Ballard et al. 1990), and (4) Gates of the Arctic National Park and Preserve (Gates), 2014-2016 (Hilderbrand et al. 2018a) (Fig. 2). While these study areas all occurred in the Arctic, fundamental differences do occur among ecosystems. Abundance and availability of Pacific salmon varies significantly among the study locations. Prior stable isotope studies of salmon consumption of bears from these studies indicate that adult female brown bears sampled from ANWR and the WBR did not utilize salmon (Hilderbrand et al. 1999). In Gates, salmon comprised $16 \%$ of the assimilated diet of female brown bears and $48 \%$ of the diet of males (NPS unpublished data). Mowat and Heard (2006) reported 28\% salmon in the diet of bears from the Noatak area in samples collected during 2003-2004. While no dietary information is available for the time period of the original study in Noatak, bears in that study area likely had the greatest access to salmon as the study area was bounded by anadromous streams with runs of all five species of Pacific salmon (Alaska Department of Fish and Game Anadromous Waters Catalog https://www.adfg. alaska.gov/sf/SARR/AWC/Catalog). In addition to salmon, brown bears across the study areas likely had access to caribou (Rangifer tarandus), Arctic ground squirrels (Spermophilus parryii), moose (Alces alces), and a variety of berries and local forbs. Soils, nutrients, and hydrology are quite disparate across study areas. ANWR and Noatak included coastal wetlands and ranged up to $\sim 1500$ and $\sim 600 \mathrm{~m}$ in elevation, respectively. Most ANWR bears were sampled on the lower elevation coastal plain and foothills of the Brooks Range. The Gates study area was more mountainous ranging from 1000 to $2000 \mathrm{~m}$. The elevation of the WBR was intermediate at $\sim 600$ to $1300 \mathrm{~m}$.

Capture, handling, aging, data collection, and values for each of the study areas are described and reported in Reynolds and Hechtel (1989), Garner et al. (1984), Ballard et al. (1990), and Hilderbrand et al. (2018a). Standardized body size measurements of body mass, body length, and skull size were collected, and mean spring litter size of cubs of the year was also reported for each population. We only included bears $\geq 8$ years of age in our analyses as structural growth is largely completed by that age (Hilderbrand et al. 2018a) and allowed us to eliminate age from our analyses. Body mass index (BMI) and Fulton's condition factor (FCF) were calculated from the available metrics as body mass divided by body length ${ }^{2}$ (BMI) and body mass divided by body length ${ }^{3}$ (FCF; see Stevenson and Woods 2006).

We compared body size, condition, and litter size independently across studies for females and males to assess potential changes with general Arctic warming trends using a one-way Analysis of Variance (ANOVA; Zar 1999). Pairwise comparisons between populations

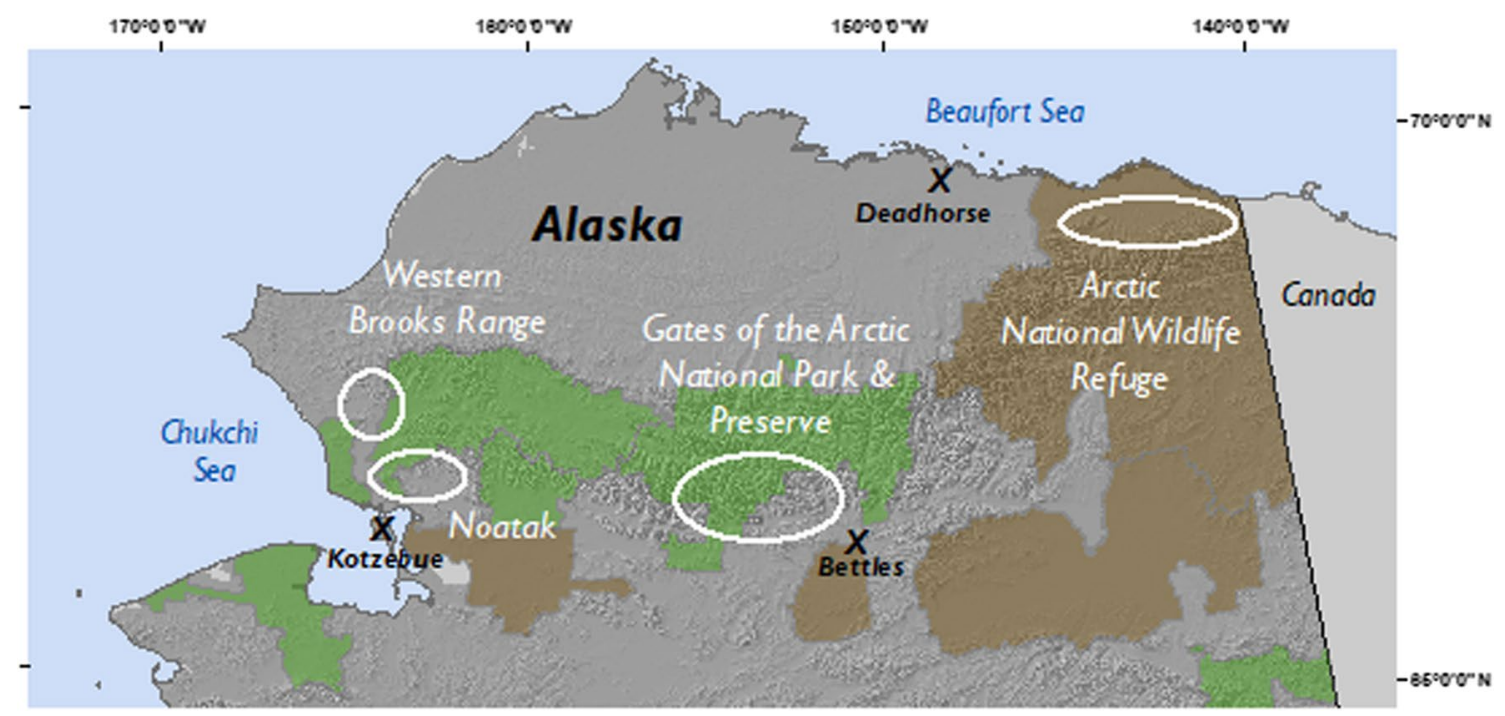

Fig. 2 Study areas, depicted by white polygons, of brown bears (Ursus arctos) in Arctic Alaska, 1977-2016. Weather stations are identified by black "x"s. National Park Service units are in green and National Wildlife Refuges in brown 
Table 1 Summary of adult morphology, body condition, and litter size of Arctic brown bear (Ursus arctos) populations (reported as mean $\pm 1 \mathrm{SD}$ with sample sizes in parenthesis)

\begin{tabular}{lcccc}
\hline & Western Brooks & ANWR & Noatak & Gates of the Arctic \\
& $1977-1979$ & $1982-1985$ & $1986-1989$ & $2014-2016$ \\
\hline Females & & & & \\
Body mass $(\mathrm{kg})$ & $109.9 \pm 17.6(28)$ & $93.5 \pm 15.1(54)$ & $111.1 \pm 15.6(24)$ & $93.9 \pm 13.6(44)$ \\
Body length $(\mathrm{cm})$ & $170.6 \pm 6.7(28)$ & $166.3 \pm 11.9(35)$ & $174.4 \pm 10.0(25)$ & $165.7 \pm 7.0(46)$ \\
Skull size $(\mathrm{cm})$ & $52.2 \pm 3.1(28)$ & $51.3 \pm 3.1(54)$ & $53.7 \pm 2.0(25)$ & $51.5 \pm 2.5(50)$ \\
Body mass index $\left(\mathrm{kg} / \mathrm{m}^{2}\right)$ & $37.8 \pm 5.4(27)$ & $35.4 \pm 6.1(35)$ & $36.4 \pm 4.0(24)$ & $34.4 \pm 4.6(43)$ \\
Fulton's CF $\left(\mathrm{kg} / \mathrm{m}^{3}\right)$ & $22.2 \pm 3.3(27)$ & $21.6 \pm 5.2(35)$ & $20.9 \pm 2.9(24)$ & $20.9 \pm 3.0(43)$ \\
Litter size & $2.1 \pm 0.7(48)$ & $1.8 \pm 0.6(36)$ & $2.3 \pm 0.7(26)$ & $1.8 \pm 0.4(10)$ \\
Males & & & & \\
Body mass $(\mathrm{kg})$ & $169.0 \pm 26.5(20)$ & $153.3 \pm 23.6(34)$ & $202.8 \pm 30.3(17)$ & $154.2 \pm 46.5(13)$ \\
Body length $(\mathrm{cm})$ & $189.4 \pm 16.7(20)$ & $185.7 \pm 9.8(23)$ & $193.7 \pm 18.8(17)$ & $183.6 \pm 8.1(13)$ \\
Skull size $(\mathrm{cm})$ & $60.2 \pm 3.3(20)$ & $57.4 \pm 2.4(33)$ & $61.0 \pm 3.5(17)$ & $57.7 \pm 5.1(16)$ \\
Body mass index $\left(\mathrm{kg} / \mathrm{m}^{2}\right)$ & $47.7 \pm 11.5(18)$ & $42.8 \pm 5.1(23)$ & $54.8 \pm 9.6(17)$ & $43.0 \pm 10.6(11)$ \\
Fulton's CF $\left(\mathrm{kg} / \mathrm{m}^{3}\right)$ & $25.9 \pm 10.2(18)$ & $23.1 \pm 3.4(23)$ & $28.8 \pm 7.3(17)$ & $23.2 \pm 4.9(11)$ \\
\hline
\end{tabular}

followed the Holm-Šidák method (Sidak 1967; Holm 1979). We assumed statistical significance at $\alpha<0.05$. We used Sigma Plot 12 (Systat Software, Inc., San Jose, CA, USA) for all statistical tests.

\section{Results}

Female brown bears varied across populations in body mass $\left(F_{(3,149)}=13.638, p<0.001\right)$, body length $\left(F_{(3,133)}=6.190, p<0.001\right)$, and skull size $\left(F_{(3,156)}=5.022\right.$, $p=0.002)$ but not in BMI $\left(F_{(3,128)}=2.588, p=0.056\right)$ or $\operatorname{FCF}\left(F_{(3,128)}=0.837, p=0.476\right.$; Table 1). Male brown bears varied across populations in body mass $\left(F_{(3,83)}=11.165, p<0.001\right)$, skull size $\left(F_{(3,85)}=5.772\right.$, $p=0.001)$, and BMI $\left(F_{(3,68)}=6.49, p<0.001\right)$ but not in body length $\left(F_{(3,72)}=1.598, p=0.198\right)$ or $\mathrm{FCF}$ $\left(F_{(3,68)}=2.584, p=0.061\right.$; Table 1$)$. Litter sizes followed the same general pattern that we found for body size measurements. Bears in Noatak had the largest litters followed by WBR. ANWR and Gates had similar litter sizes. The differences in litter size across populations were not significant at the $\alpha<0.05$ level $\left(F_{(3,119)}=2.632\right.$, $p=0.053$; Table 1).

Where significant differences did exist, bears in Noatak were generally the largest though females from Noatak did not differ statistically from WBR females (Tables 1, $2,3)$. Both males and females from ANWR and Gates did not differ in any metrics assessed. Females from ANWR and Gates were smaller than those from WBR and Noatak, but males were not significantly smaller than WBR bears (Tables 1, 2, 3).
Table 2 Pairwise comparisons (Holm-Šidák method, $p$ values presented) following one-way ANOVAs of body size metrics of female brown bears (Ursus arctos) from the Western Brooks Range (WBR; 1977-1979). Arctic National Wildlife Refuge (ANWR; 1982-1985), Noatak (1986-1989), and Gates of Arctic National Park and Preserve (Gates; 2014-2016)

\begin{tabular}{lrll}
\hline & Body mass & Body length & Skull size \\
\hline Noatak vs. ANWR & $<0.001$ & 0.004 & 0.002 \\
Noatak vs. Gates & $<0.001$ & 0.001 & 0.006 \\
Noatak vs. WBR & 0.953 & 0.247 & 0.197 \\
WBR vs. ANWR & $<0.001$ & 0.172 & 0.371 \\
WBR vs. Gates & $<0.001$ & 0.099 & 0.425 \\
Gates vs. ANWR & 0.899 & 0.783 & 0.739 \\
\hline
\end{tabular}

Sample sizes are listed in Table 1

Table 3 Pairwise comparisons (Holm-Šidák method) following oneway ANOVAs of body size and condition metrics of male brown bears (Ursus arctos) from the Western Brooks Range (WBR; 19771979), Arctic National Wildlife Refuge (ANWR; 1982-1985), Noatak (1986-1989), and Gates of Arctic National Park and Preserve (Gates; 2014-2016)

\begin{tabular}{lrlc}
\hline & Body mass & Skull size & Body mass index \\
\hline Noatak vs. ANWR & $<0.001$ & 0.004 & $<0.001$ \\
Noatak vs. Gates & $<0.001$ & 0.026 & 0.007 \\
Noatak vs. WBR & 0.004 & 0.707 & 0.100 \\
WBR vs. ANWR & 0.193 & 0.029 & 0.245 \\
WBR vs. Gates & 0.317 & 0.096 & 0.324 \\
Gates vs. ANWR & 0.927 & 0.807 & 0.953 \\
\hline
\end{tabular}

Sample sizes are listed in Table 1

\section{Discussion}

While circumpolar trends in temperature, snow-free days, 
and plant productivity are all generally increasing, the magnitude and direction of change in these metrics vary locally based on elevation, soil chemistry, geologic history, hydrology, and plant community structure (Raynolds et al. 2006; Verbyla 2008; Swanson 2017). Figure 1 illustrates differences in temperatures and trends for three communities near the study areas (Fig. 2).

Brown bears from the Noatak study area (1986-1989) were generally the largest and most productive of the four areas. This finding suggests that brown bears with greater access to food resources and that live in an area with more favorable physiography would have larger body and litter sizes. Noatak bears had access to and utilized salmon as a significant portion of their diet (Mowat and Heard 2006) and resided at low elevations with earlier snow melt and longer growing seasons than higher elevation study areas (Macander et al. 2015).

Despite consuming salmon (NPS unpublished data), brown bears from Gates were similar in size to brown bears from ANWR (1982-1985). Satellite data from 1982 to 2003 suggest that vegetative productivity (as indexed by maximum Normalized Difference Vegetation Index values) decreased in the Gates study but was slightly increasing in portions of the other three study areas (see Fig. 3 in Verbyla 2008). Moreover, Gates is comprised of a greater proportion of alpine habitats with sparser vegetation than either Noatak or WBR (see Fig. 3 in Swanson 2017) and this has implications for soils, vegetation, and both snowfall and duration of snow cover, which is generally decreasing (Swanson 2017). This in turn affects the availability of food resources for brown bears. Thus, our results suggest that physiography, local weather, and growing season can dampen (or enhance) the importance of local availability of food resources for brown bears and thereby affect body and litter sizes. That said, bears can achieve similar condition despite differences in dietary composition if a broad enough range of food resources are available (Lafferty et al. 2015; Mangipane et al. 2017). Our results highlight that the interactions and effects of biotic and abiotic factors are complex and may vary with local conditions.

Brown bears from WBR (1977-1979) were generally larger and more productive than bears from ANWR (1982-1984) even though prior studies indicated neither population utilized salmon (Hilderbrand et al. 1999). Brown bears have been recently observed consuming salmon in the Kelly River which lies in the WBR study area (M. Sorum, pers. obs.) reflecting either a shift in distribution and use of salmon by bears or that the prior sampling did not include salmon-consuming bears. Both WBR and ANWR populations have access to caribou as their study areas overlapped the calving and/or summer range of the Western Arctic and Porcupine caribou herds, respectively (https://www.adfg.alaska.gov/static/species/ speciesinfo/caribou/images/caribou_herds.jpg). While the study areas are at similar elevations, the mean July temperature and length of the growing season was substantially greater in WBR than in ANWR (see Kotzebue versus Deadhorse in Fig. 1 as surrogates for study locations, respectively). Thus, we predict that where climatic shifts lead to greater vegetative productivity and longer growing seasons for caribou, brown bear productivity may benefit from greater access to this high-quality food resource.

Body size, body condition, and productivity are ultimately driven by the ability of brown bears to access and accumulate nutrients to support the costs of maintenance and reproduction. Within a given ecosystem, the availability and use of salmon benefits individual bears, but at a population level, the availability of salmon alone may not necessarily overcome the reduced availability or quality of vegetation due to poorer physiography, soils, and/or shorter growing seasons. In addition, the effects of generally warming temperatures in the Arctic on salmon are uncertain and will likely be regionally variable (Schindler and Rogers 2009) as salmon populations may be positively or negatively affected by changes in hydrology, fire regime, human development, and habitat diversity (Schoen et al. 2017). Relative to vegetative resources either used directly by brown bears or by species preyed upon by bears, elevation, soil chemistry, local temperatures, and the duration of the snow-free season, all have the potential to affect ecosystem productivity directly and, thus, indirectly influence the size, condition, and productivity of brown bears.

Our findings emphasize that local management decisions regarding brown bear populations and human activities should be informed by local data. Further, application or extrapolation of data from adjacent areas may lead to spurious predictions and decisions if the differential effects of climatic shifts, physiography, and availability of food resources are not accounted for. We suggest that given the level of variation and uncertainty across populations, conservative management, especially relative to harvest, is warranted when local data are unavailable. Finally, we believe that replicated studies of specific populations of interest across time coupled with local climate data would be more informative than the generalizations and associated uncertainty we identified by comparing the results from individual studies separated in both space and time.

Acknowledgements Prior work led by W. Ballard, G. Garner, and H. Reynolds was critical to the development of this manuscript. The authors thank K. Nicholson, H. Golden, W. Leacock, and an anonymous reviewer for comments that improved the manuscript greatly. Funding and staff support were provided by the National Park Service and U.S. Geological Survey. Use of trade, firm, or product names is for descriptive purposes only and does not imply endorsement by the U. S. Government. 


\section{Compliance with Ethical Standards}

Conflicts of interest The authors have no conflicts of interest related to the subject matter of this publication. Data used in this study are from prior published work in Western Brooks Range (WBR), Arctic National Wildlife Refuge (ANWR), Noatak, and Gates of the Arctic National Park and Preserve (Gates).

Open Access This article is distributed under the terms of the Creative Commons Attribution 4.0 International License (http://creativeco mmons.org/licenses/by/4.0/), which permits unrestricted use, distribution, and reproduction in any medium, provided you give appropriate credit to the original author(s) and the source, provide a link to the Creative Commons license, and indicate if changes were made.

\section{References}

Ballard WB, Ayres LA, Fancy SG, Reed DJ, Roney KE (1990) Demography of Noatak grizzly bears in relation to human exploitation and mining development. Prog Rep Proj W-23-2, Study 4.20. Alaska Dept Fish Game, Juneau, Alaska, USA

Clement JP, Bengtson JL, Kelly BP (2013) Managing for the future in a rapidly changing arctic: a report to the president. Interagency working group on coordination of domestic energy development and permitting in Alaska

Comiso JC, Hall DK (2014) Climate trends in the Arctic as observed from space. WIREs Clim Change 5:389-409. https://doi.org/10.1002/ wcc. 277

Deacy W, Leacock W, Armstrong JB, Stanford JA (2016) Kodiak brown bears surf the salmon red wave: direct evidence from GPS collared individuals. Ecology 97:1091-1098

Farley SD, Robbins CT (1995) Lactation, hibernation, and mass dynamics of American black bears and grizzly bears. Can J Zool 73:2216-2222

Garner GW, Reynolds HV, Martin LD, Wilmers TJ, Doyle TJ (1984) Ecology of brown bears inhabiting the coastal plain and adjacent foothills and mountains of the northeastern portion of the Arctic National Wildlife Refuge. ANWR Prog Rep Num FY 84-11, Fairbanks, Alaska, USA

Gonzalez P, Wang F, Notaro M, Vimont DJ, Williams JW (2018) Disproportionate magnitude of climate change in United States national parks. Environ Res Lett 13:104001. https://doi. org/10.1088/1748-9326/aade09

Hilderbrand GV, Schwartz CC, Robbins CT, Jacoby ME, Hanley TA, Arthur SM, Servheen C (1999) Importance of meat, particularly salmon to body size, population productivity, and conservation of North American brown bears. Can J Zool 77:132-138

Hilderbrand GV, Schwartz CC, Robbins CT, Hanley TA (2000) Effect of hibernation and reproductive status on body mass and condition of coastal brown bears. J Wildl Manag 64:178-183

Hilderbrand GV, Gustine DD, Mangipane B, Joly K, Leacock W, Mangipane L, Erlenbach J, Sorum MS, Cameron MD, Belant JL, Cambier T (2018) Body size and lean mass of brown bears across and within four diverse ecosystems. J Zool 305:53-62. https://doi. org/10.1111/jzo.12536

Hilderbrand GV, Gustine DD, Mangipane B, Joly K, Leacock W, Manipane L, Erlenbach J, Sorum MS, Cameron MD, Belant JL, Cambier T (2018) Plasticity in physiological condition of female brown bears across diverse ecosystems. Pol Biol 41:773-780. https://doi.org/10.1007/s00300-017-2238-5

Hinzman LD, Deal CJ, McGuire AD, Mernild SH, Polyakov IV, Walsh JE (2013) Trajectory of the Arctic as an integrated system. Ecol Appl 23:1837-1868
Holm S (1979) A simple sequentially rejective multiple test procedure. Scand J Stat 6:65-70

Holt EA, McCune B, Neitlich P (2007) Succession and community gradients of Arctic macrolichens and their relation to substrate, topography, and rockiness. Pac Northwest Fungi 2:1-21

Intergovernmental Panel on Climate Change (IPCC) (2007) Climate change 2007: the physical science basis. Cambridge University Press, Cambridge

Lafferty DJ, Belant JL, Phillips DL (2015) Testing the niche variation hypothesis with a measure of body condition. Oikos 124:732-740

Macander MJ, Swingley CS, Joly K, Raynolds M (2015) Landsat-based snow persistence map for northwest Alaska. Remote Sens Environ 163:23-31

Mangipane LS, Belant JL, Lafferty DJR, Gustine DD, Hiller TL, Colvin ME, Mangipane BA, Hilderbrand GV (2017) Dietary plasticity in a nutrient-rich system does not influence brown bear (Ursus arctos) body condition or denning. Pol Biol 41:763-772

Mowat G, Heard DC (2006) Major components of grizzly bear diet across North America. Can J Zool 84:473-489

Pigeon KE, Nielsen SE, Stenhouse GB, Côté SD (2014) Den selection by grizzly bears on a managed landscape. J Mamm 95:559-571. https://doi.org/10.1644/13-MAMM-A-137

Pigeon KE, Côté SD, Stenhouse GB (2016) Assessing den selection and den characteristics of grizzly bears. J Wildl Manag 80:884893. https://doi.org/10.1002/jwmg.1069

Raynolds MK, Walker DA, Maier HA (2006) NDVI patterns and phytomass distribution in the circumpolar Arctic. Remote Sens Environ 102:271-281

Reynolds HV III, Hechtel JL (1989) Grizzly bear population ecology in the Western Brooks Range Alaska. Prog Rep Alaska Department of Fish Game, Fairbanks, Alaska, USA

Schindler DE, Rogers LA (2009) Responses of Pacific salmon populations to climate variation in freshwater ecosystems. Am Fish $\mathrm{S}$ S 70:1-15

Schoen ER, Wipfli MS, Trammell EJ, Rinella DJ, Floyd AL, Grunblatt J, McCarthy MD, Meyer BE, Morton JM, Powell JE, Prakash A, Reimer MN, Stuefer SL, Toniolo H, Wells BM, Witmer FDW (2017) Future of Pacific salmon in the face of environmental change: lessons from one of the world's remaining productive salmon regions. Fisheries 42(10):538-553

Sidak Z (1967) Rectangular confidence region for the means of multivariate normal distributions. J Am Stat Assoc 62:626-633

Stevenson RD, Woods WA Jr (2006) Condition indices for conservation: new uses for evolving tools. Integr Comp Biol 46:1169-1190

Swanson DK (2017) Trends in greenness and snow cover in Alaska's Arctic National Parks, 2000-2016 Remote Sens. https://doi. org/10.3390/rs 9060514

Tape K, Sturm M, Racine C (2006) The evidence for shrub expansion in northern Alaska and the pan-Arctic. Glob Change Biol 12:1-17. https://doi.org/10.1111/j.1365-2486.2006.01128.x

Van Hemert C, Flint PL, Udevitz MS, Koch JC, Atwood TC, Oakley KL, Pearce JM (2015) Forecasting wildlife response to rapid warming in the Alaska Arctic. Bioscience 65:718-728

Verbyla D (2008) The greening and browning of Alaska based on 1982-2003 satellite data. Global Ecol Biogeogr 17:547-555

Zar JH (1999) Biostatistical analysis, 4th edn. Prentice Hall Inc., Upper Saddle River

Publisher's Note Springer Nature remains neutral with regard to jurisdictional claims in published maps and institutional affiliations. 